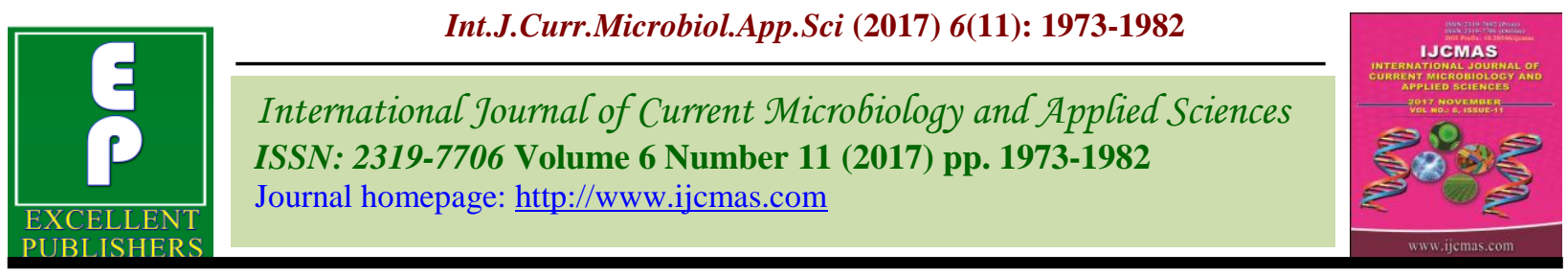

Original Research Article

https://doi.org/10.20546/ijcmas.2017.611.234

\title{
Genetic Variability Amongst Xanthomonas axonopodis pv. punicae Studied by RAPD Banding Pattern Analysis
}

\author{
S.P. Sahane, C.V. Ambadkar* and K.D. Navgire \\ Department of Plant Pathology, College of Agriculture, Latur, Vasantrao Naik Marathwada \\ Krishi Vidyapeeth, Parbhani 431402 (M.S.), India \\ *Corresponding author
}

A B S T R A C T

Keywords

Bacterial blight,

Pomegranate,

Polymorphism,

RAPD, Xanthomonas

axonopodis pv.

Punicae.

Article Info

Accepted:

17 September 2017

Available Online:

10 November 2017
Bacterial blight disease of pomegranate caused by Xanthomonas axonopodis pv. punicaeis one of the most destructive disease of pomegranate (Punica granatum) inflicting considerable quantitative and qualitative losses. Mostly the disease occurred on leaves, stems and fruits. The disease is characterized by small, irregular, translucent, water soaked spots with light to dark necrotic centre surrounded by prominent yellow margin on leaves. The isolates were made from the symptomatic samples collected from five different locations viz. Yekurga (Osmanabad), Killari (Latur), Kej (Beed), Nimgaon and Badnapur belonging to Jalna district of Maharashtra state, India. The primer OPA09, ABA05 and ABA07 was found most significant by producing 100 per cent polymorphism amongst 03 strains of Latur, Osmanabad and Beed districts, whereas, Primer OPC03, OPH02 and OPC20 was found most significant by producing 100, 100 and 90.91 per cent polymorphism amongst 02 strains of Jalna districts. These results indicate a high level of genomic variability among the isolates even within the different geographical regions.

\section{Introduction}

Pomegranate (Punica granatum L.) is a favourite table fruit in tropical and subtropical regions of the world which belongs to family punicae. It is native to Iran but extensively cultivated in Mediterranean regions especially in Spain, Morocco, Egypt and Afghanistan. Pomegranate is being cultivated on an area of 193.0 thousand ha in India with production of 2198.0 thousand metric tonnes and productivity of 11.3 metric tonnes per ha (Anonymous, 2016). The Maharashtra state, alone occupies an area of 128.65 thousand ha. followed by Karnataka (23.23 thousand ha.), Gujarat (14.77 thousand ha.) and Andhra Pradesh (5.38 thousand ha.). Even
Maharashtra is having largest area under pomegranate cultivation; production and productivity are 1197.71 thousand metric tonnes and 9.31 metric tonnes per ha, respectively (Anonymous, 2015). Incidence of bacterial blight disease of pomegranate caused by Xanthomonas axonopodis $p v$. punicae (Xap) is the major obstacle and limiting factor in Maharashtra state which alone accounts for loss of cultivated area, particularly in Nasik, Solapur, Sangli and Ahmednagar districts. Bacterial blight infection results in appearance of water soaked oily spot symptoms on leaves, stems and fruits which consequently decreases fruit 
production and market value. Severity of incidence and losses varies among different isolates and influenced by existing climatic conditions and geographical distribution (Mondal and Sharma, 2009; Mondal and Singh, 2009, Petersen et al., 2010, Mondal et al., 2012). The present investigation was carried out to understand molecular diversity in Xanthomonas axonopodis pv. punicae isolated from different parts of Jalna, Latur, Osmanabad and Beed district of Maharashtra state, India.

\section{Materials and Methods}

\section{Collection of diseased sample and isolation of pathogen}

The diseased leaves samples of Pomegranate showing typical symptoms of bacterial blight were collected for isolation of bacterium Xanthomonas axonopodis pv. punicae from five different locations viz. Yekurga (Osmanabad), Killari (Latur), Kej (Beed), Nimgaon and Badnapur (Jalna) belonging to different region of Maharashtra state during in the month of September and October, 2016. The isolation of bacterium was carried out by tissue isolation method on Nutrient Agar (NA) medium at 25 to $28{ }^{\circ} \mathrm{C}$ for 3-5 days. Welldeveloped, separated, typical, bright yellow, mucoid colonies on plate were further streaked onto the agar slants containing the NA medium and incubated at 25 to $28{ }^{\circ} \mathrm{C}$ for 3 days. Then cultures were stored in the refrigerator at $4{ }^{0} \mathrm{C}$, which served as a stock culture for further studies. The isolates were designated as per different locations viz. Yekurga (XapI), Killari (XapII), Kej (XapIII), Nimgaon (XapIV) and Badnapur (XapV).

\section{DNA isolation}

DNA extraction from 5 samples of bacteria was carried out using SDS-Ammonium acetate method. Loop full of each culture was suspended in $0.2 \mathrm{ml}$ extraction buffer $(50 \mathrm{mM}$
Tris-HCl, 50mM EDTA, 250mM NaCl, $1.5 \%$ Sucrose) and $50 \mu \mathrm{l}$ of SDS (20\%) was added to it. The solution was vortexed and incubated for $30 \mathrm{~min}$ at $65^{\circ} \mathrm{C} .50 \mu \mathrm{l}$ of $7.5 \mathrm{M}$ Ammonium acetate was then added to the above solution and mixed by inverting. The tubes were incubated at $4^{0} \mathrm{C}$ for 15 minutes. DNA was extracted using 1 volume of chloroform: isoamyl alcohol mixture (24:1) and centrifuged at $10000 \mathrm{rpm}$ for 5mins. Double volume of ethanol (96-100\%) was added to the aqueous phase in a new tube, inverted twice and allowed to stand at $4^{0} \mathrm{C}$ for 30 minutes. The mixture was then centrifuged at $10000 \mathrm{rpm}$ for 15 minutes. After drying for few seconds pellet was dissolved in $50 \mu \mathrm{l}$ elution buffer $(10 \mathrm{mM}$ Tris- $\mathrm{HCl}, 1 \mathrm{mM}$ EDTA). Agarose gel electrophoresis was performed to check the presence of DNA using $0.8 \%$ Agarose. The DNA was stored at $4^{0} \mathrm{C}$ for further use.

\section{DNA quantification}

DNA concentration was determined using Quant-iT ${ }^{\mathrm{TM}}$ dsDNA BR Assay Kit of Invitrogen (Table 1). Quant-iT TM working solution was prepared for 2 samples and 2 standards by diluting the Quant-iT ${ }^{\mathrm{TM}} \mathrm{dsDNA}$ BR reagent 1:200 in Quant-iT ${ }^{\mathrm{TM}} \mathrm{dsDNA} B R$ buffer in a plastic container. $190 \mu \mathrm{l}$ of working solution was dispensed in 2 Qubit assay tubes for standards and $198 \mu \mathrm{l}$ was dispensed in each sample tube. $10 \mu \mathrm{l}$ of each of the two standards were added to the respective standard tubes and $2 \mu \mathrm{l}$ of each of the sample was added to the respective sample tubes.

The tubes were vortexed and incubated at room temperature for 2 minutes. The QuantiT ${ }^{\mathrm{TM}}$ dsDNA BR was chosen on Qubit ${ }^{\mathrm{TM}}$ fluorometer and calibration done using the two standards. Sample readings were taken and calculated for $2 \mu \mathrm{l}$. The results were obtained in $\mu \mathrm{g} / \mathrm{ml}$. 


\section{RAPD PCR protocol}

The DNA isolated from five bacterial samples was subjected to polymerase chain reaction (PCR) amplification with 5 random 10-mer primers (Synthesized by GeNei, Bangalore, India) (Table 2). Amplification of genomic DNA was carried out in $25 \mu \mathrm{l}$ reaction mixture containing $1 \mu \mathrm{l}(20 \mathrm{ng} / \mu \mathrm{l})$ genomic DNA as template, $5 \mu 1$ PCR master mix $5 \mathrm{X}$ qARTA. Taq Master Mix (1.5mM MgCl2) from Qartabio (QTMM1.5-200), $1 \mu$ primer (concentration $100 \mathrm{pM}$ ) and $18 \mu \mathrm{l}$ of nuclease free water. DNA amplification was performed in a DNA thermal cycler (Biometra, Germany). PCR conditions were set as first cycle of $5 \mathrm{~min}$ at $94^{\circ} \mathrm{C}$ for template denaturation, followed by 40 cycles of $45 \mathrm{sec}$ at $94^{\circ} \mathrm{C}, 45 \mathrm{sec}$ at $37^{\circ} \mathrm{C}$ and $1 \mathrm{~min} 30 \mathrm{sec}$ at $72^{\circ} \mathrm{C}$. An additional cycle of $5 \mathrm{~min}$ at $72^{\circ} \mathrm{C}$ was used for final primer extension. Amplified products were analyzed by electrophoresis on 1.4 per cent agarose gel.

\section{Gel electrophoresis}

Agarose powder (SeaKem LE, 50004L) was mixed with 1X TAE buffer (Fermentas, B49) to prepare a solution. 1X TAE buffer was prepared by diluting 50X TAE buffer of Fermentas (Composition: 43.12g Tris, 22g Acetic acid, 2.96g EDTA in $1000 \mathrm{ml}$ distilled water). The solution was heated to dissolve agarose. Gel red stain (10000X Biotium$41003)$ was added $(0.3 \mu \mathrm{l}$ in $30 \mathrm{ml})$ to it. The hot, clear agarose solution was poured into the tray and was allowed to cool. After cooling the gel tray was placed in an electrophoresis chamber, which was filled with 1X TAE buffer, covering the gel. This allows electrical current from poles at either end of the gel to flow through the gel. Finally, DNA samples were mixed with $6 \mathrm{X}$ loading dye (Fermentas, R0611) in 5:1 ratio and loaded on the gel. Electrophoresis was performed and Gel was observed through UV trans-illuminator to check for presence of DNA.

\section{Scoring of amplified fragments}

The amplified profiles for all the primers were compared with each other and bands of DNA fragment were scored as ' 1 ' for presence and ' 0 ' for absence, generating ' 0 ' and ' 1 ' matrix. Per cent polymorphism was calculated by using the formula.

Number of polymorphic bands Per cent polymorphism = ------------ X 100

Total number of bands

\section{Results and Discussion}

Molecular variability of different Xap isolates collected from Latur, Osmanabad and Beed district

The detail profile of DNA bands of different primers for three isolates of $X$. axonopodis pv. Punicae is presented in Table 3. Total 20 RAPD primers were used to detect the genetic diversity, out of them 5 primers exhibited good amplification with scorable bands. A total of 25 DNA bands were detected by 5 primers, of which, 19 bands were found polymorphic. Among these primers, OPA-09, ABA-05 and ABA-07 were shown 100 per cent polymorphism. Remaining ABA-16 and UBC-478 were shown 60 per cent and 0 per cent polymorphism, respectively. The results of RAPD analysis revealed that a total of 76 per cent polymorphism was found between the isolates, indicating molecular variability among the $X$. axonopodis $\mathrm{pv}$. punicae isolates. Information on the banding pattern for all the primers were used to determine genetic distance between the isolates and to construct a dendrogram by using unweighted pair group method (Nei's). Based on the Nei's similarity coefficient a genetic similarity matrix was constructed to 
assess the genetic relatedness among the three isolates. The similarity coefficient value was ranged from 0.27 to 0.91 across three isolates indicating high degree of genetic variation.

This ultimately means high range of genetic diversity among the isolates studied. The genetic similarity coefficient to an extent of 1.13 was recorded between Xap2 and Xap 1 isolates followed by 0.91 between Xap-3 and Xap-2 isolates. Least genetic similarity coefficient 0.27 was observed in between Xap3 and Xap1. The dendrogram constructed by Nei's for RAPD analysis shows that isolates can be grouped into two major clusters viz. A and B (Fig. 3) Cluster A divided into two sub clusters namely cluster A1 and cluster A2. Sub cluster A1 showed isolates, Xap1 (Yekurga), and whereas Sub cluster A2 having single isolate Xap-3 (Kej). Cluster B was found distinct from Cluster A containing single isolate Xap-2 (Killari).

Table.1 DNA concentration of bacterial samples

\begin{tabular}{|c|c|c|}
\hline Sr. no. & Sample code & DNA concentration \\
\hline $\mathbf{0 1}$ & Xap-1 & $40.0 \mu \mathrm{g} / \mathrm{ml}$ \\
\hline $\mathbf{0 2}$ & $X a p-2$ & $36.4 \mu \mathrm{g} / \mathrm{ml}$ \\
\hline $\mathbf{0 3}$ & $X a p-3$ & $53.1 \mu \mathrm{g} / \mathrm{ml}$ \\
\hline $\mathbf{0 4}$ & $X a p-4$ & $50.2 \mu \mathrm{g} / \mathrm{ml}$ \\
\hline $\mathbf{0 5}$ & $X a p-5$ & $38.4 \mu \mathrm{g} / \mathrm{ml}$ \\
\hline
\end{tabular}

Table.2 Primers used for PCR amplification of Xap-1, Xap-2 and Xap-3 samples

\begin{tabular}{|c|c|}
\hline Primer & Sequences 5'-3 \\
\hline OPA09 & GGGTAACGCC \\
\hline ABA05 & AGGGGTCTTG \\
\hline ABA07 & GAAACGGGTG \\
\hline ABA16 & AGCCAGGCGAA \\
\hline UBC 478 & CGAGCTGGTC \\
\hline
\end{tabular}

Table.3 DNA banding profile and per cent polymorphism observed in samples of Latur Osmanabad and Beed district (Xap-1, Xap-2, Xap-3)

\begin{tabular}{|c|l|l|c|c|c|}
\hline Sr. no. & $\begin{array}{c}\text { Primer } \\
\text { code }\end{array}$ & $\begin{array}{c}\text { Primer Sequences } \\
\text { 5'-3 }\end{array}$ & Total band & $\begin{array}{c}\text { Polymorphic } \\
\text { band }\end{array}$ & \% Polymorphism \\
\hline $\mathbf{0 1}$ & OPA09 & GGGTAACGCC & 6 & 6 & $100 \%$ \\
\hline $\mathbf{0 2}$ & ABA05 & AGGGGTCTTG & 5 & 5 & $100 \%$ \\
\hline $\mathbf{0 3}$ & ABA07 & GAAACGGGTG & 5 & 5 & $100 \%$ \\
\hline $\mathbf{0 4}$ & ABA16 & AGCCAGGCGAA & 5 & 3 & $60 \%$ \\
\hline $\mathbf{0 5}$ & UBC 478 & CGAGCTGGTC & 4 & 0 & $0 \%$ \\
\hline & Total & & $\mathbf{2 5}$ & $\mathbf{1 9}$ & $\mathbf{7 6 \%}$ \\
\hline
\end{tabular}


Table.4 Nei's original measures of genetic identity and genetic distance

\begin{tabular}{|c|c|c|c|}
\hline pop ID & Xap-1 & Xap-2 & Xap-3 \\
\hline Xap-1 & $* * * *$ & 0.3200 & 0.7600 \\
\hline Xap-2 & 1.1394 & **** & 0.4000 \\
\hline Xap-3 & 0.2744 & 0.9163 & $* * * *$ \\
\hline
\end{tabular}

Table.5 Primers used for PCR amplification of Xap-4 and Xap-5 samples

\begin{tabular}{|l|l|}
\hline Primer & Sequences 5'-3' \\
\hline OPC03 & GGGGGTCTTT \\
\hline OPC20 & ACTTCGCCAC \\
\hline OPH02 & TCGGACGTGA \\
\hline OPH12 & ACGCGCATGT \\
\hline OPH16 & GAGCGTCGAA \\
\hline
\end{tabular}

Table.6 DNA banding profile and per cent polymorphism observed in samples of Jalna district (Xap-4 and Xap-5)

\begin{tabular}{|c|c|c|c|c|c|}
\hline Sr. no. & $\begin{array}{c}\text { Primer } \\
\text { code }\end{array}$ & $\begin{array}{c}\text { Primer Sequences } \\
\mathbf{5} \text {-3 }\end{array}$ & $\begin{array}{c}\text { Total } \\
\text { band }\end{array}$ & $\begin{array}{c}\text { Polymorphic } \\
\text { band }\end{array}$ & \% Polymorphism \\
\hline 01 & OPC03 & GGGGGTCTTT & 4 & 4 & $100 \%$ \\
\hline 02 & OPC20 & ACTTCGCCAC & 11 & 10 & $90.91 \%$ \\
\hline 03 & OPH02 & TCGGACGTGA & 7 & 7 & $100 \%$ \\
\hline 04 & OPH12 & ACGCGCATGT & 6 & 5 & $83.33 \%$ \\
\hline 05 & OPH16 & GAGCGTCGAA & 5 & 3 & $60 \%$ \\
\hline & Total & & 33 & 29 & $87.88 \%$ \\
\hline
\end{tabular}

Table.7 Nei's original measures of genetic identity and genetic distance

\begin{tabular}{|c|c|c|}
\hline pop ID & Xap-4 & Xap-5 \\
\hline Xap-4 & $* * * *$ & 0.1212 \\
\hline Xap-5 & 2.1102 & $* * * *$ \\
\hline
\end{tabular}


Fig.1 Genomic DNA for the Xap-1, Xap-2, Xap-3, Xap-4 and Xap-5 samples

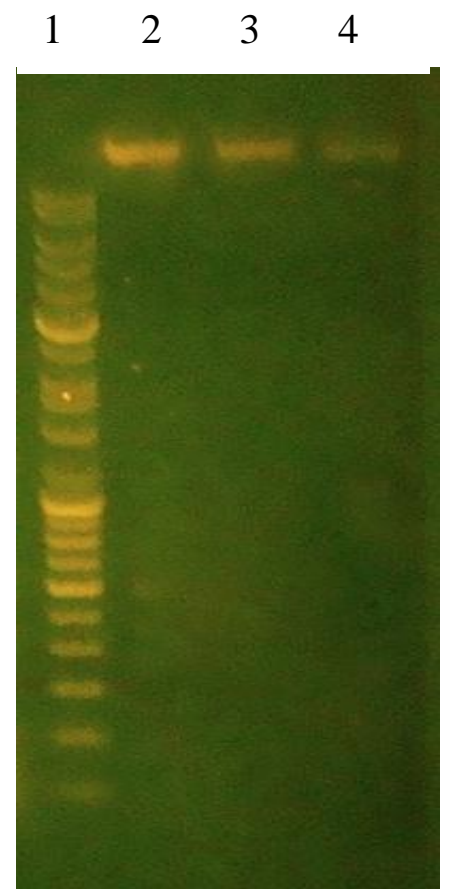

Lane 1: High range DNA marker of GeNei Lane 2-4: Genomic DNA of Xap-1, Xap-2, Xap-3 samples

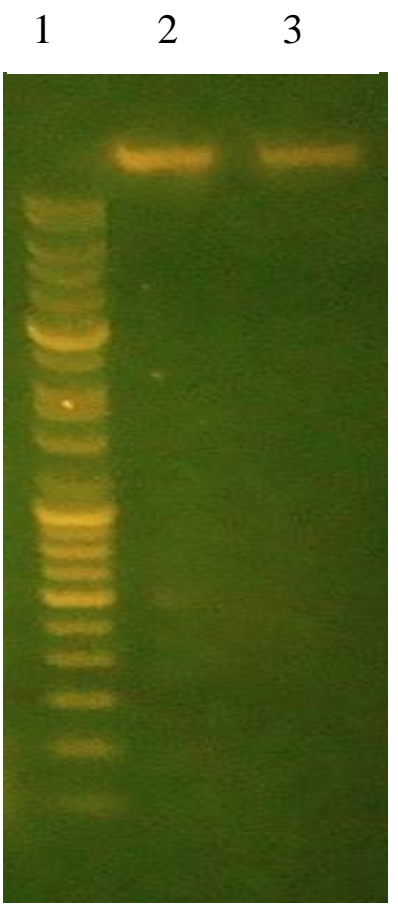

Lane 1: High range DNA marker of GeNei Lane 2-3: Genomic DNA for Xap-4 and Xap-5 samples.

Fig.2 RAPD profile of Xap-1, Xap-2 and Xap-3 samples

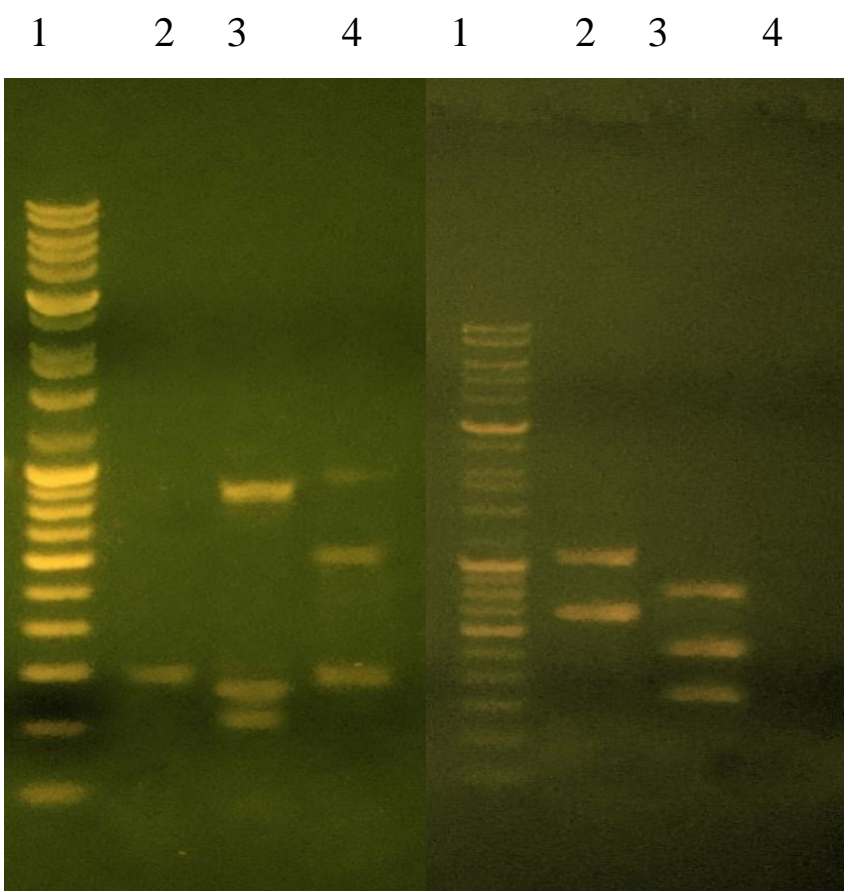

OPA-09
ABA-05

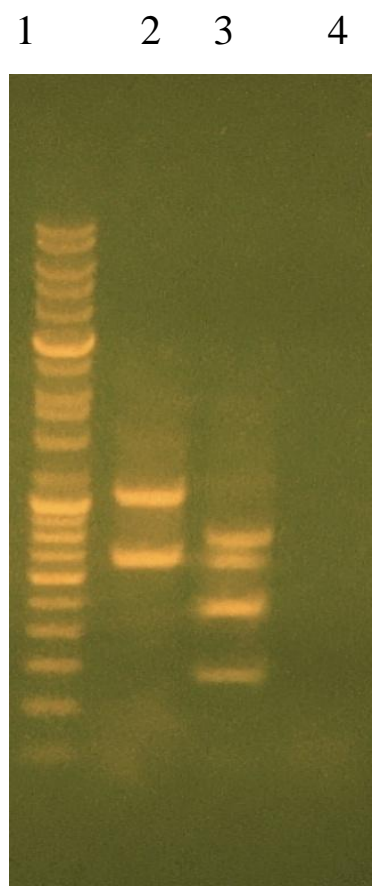

ABA-07 


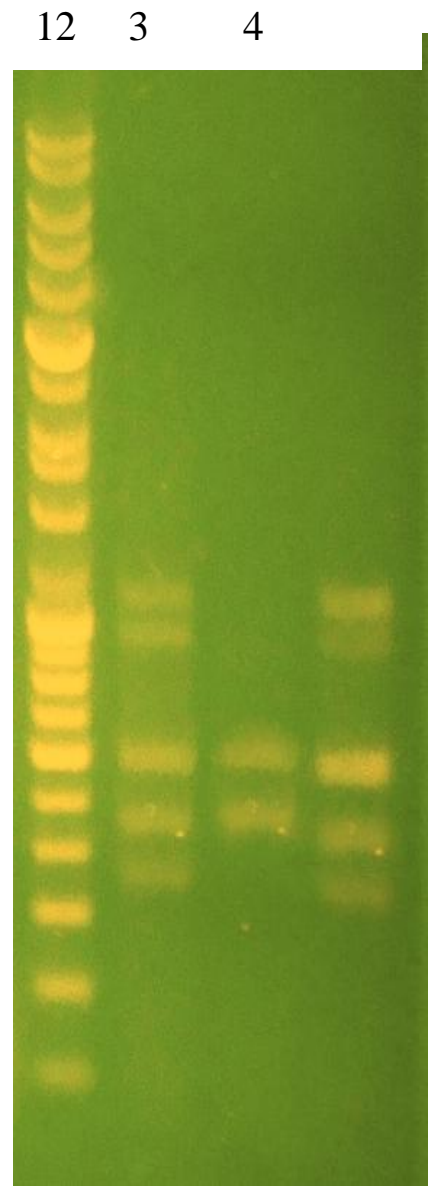

ABA-16

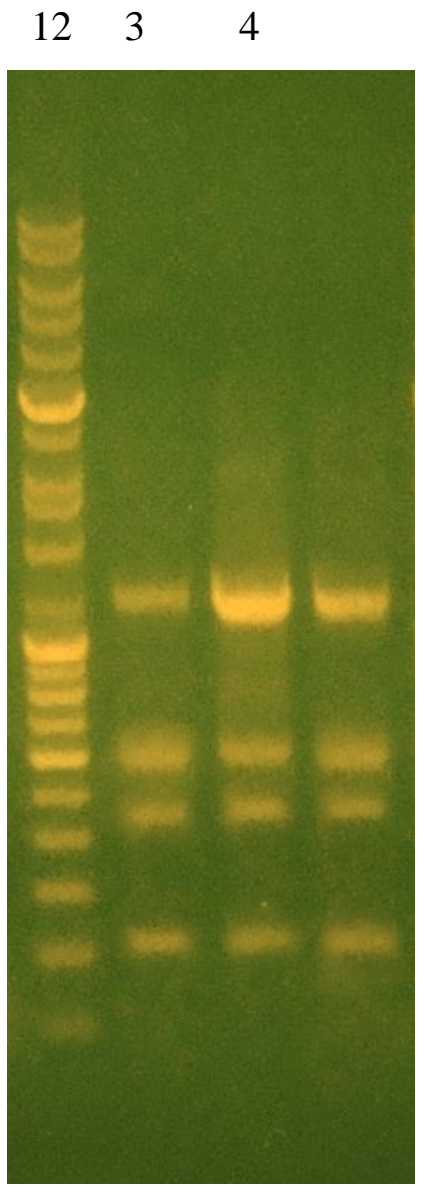

UBC-478

Fig.3 Dendogram based on Nei's genetic distance

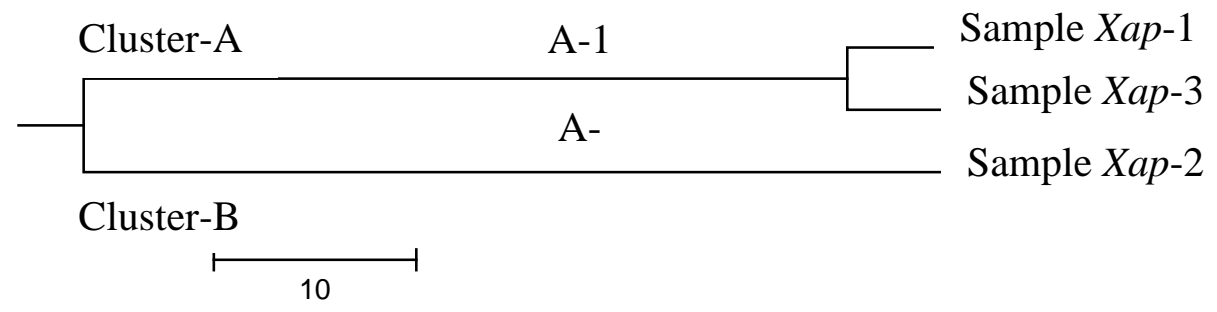

Fig.4 Dendogram based on Nei's genetic distance

Cluster-A

Cluster-B
Sample Xap-4

Sample Xap-5 
Fig.5 RAPD profile for Xap-4 and Xap-5 samples
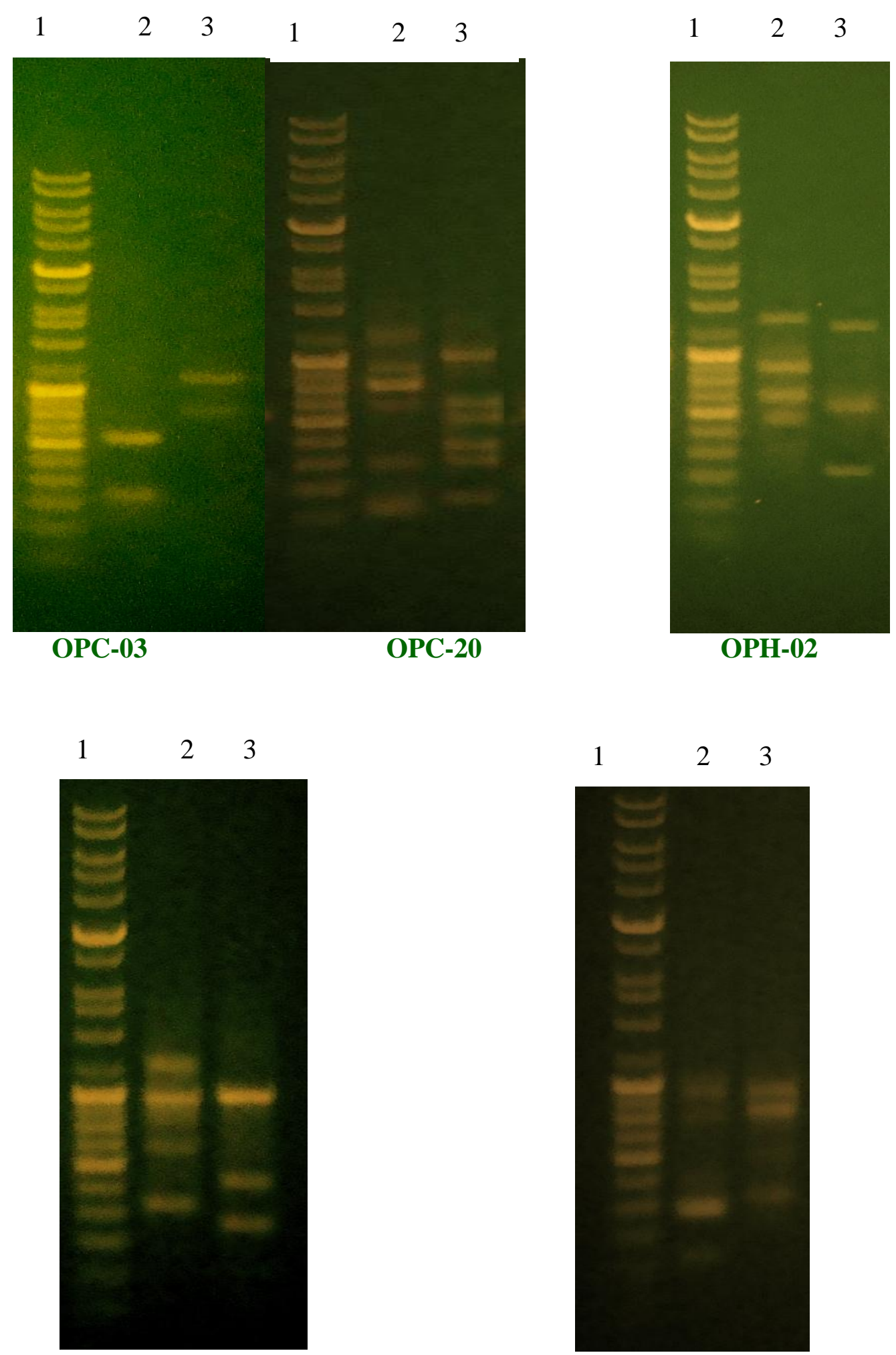

OPH-12

OPH-16 
Molecular variability of Xap isolates collected from Jalna district (Xap-4 and Xap-5)

The detail profile of DNA bands of different primers for two isolates of $X$. axonopodis $p v$. punicaeis presented in Table 6 . The data presented in revealed that total 20 RAPD primers were used to detect the genetic diversity, out of them 5 primers exhibited good amplification with scorable bands. A total of 33 DNA bands were detected by 5 primers, of which, 29 bands were found polymorphic. Among these primers, OPC-03 and OPH-02 were shown $100 \%$ polymorphism. Remaining OPC-20, OPH-12 and OPH1-6 were shown $90.91 \%, 83.33 \%$ and $60 \%$ polymorphism respectively. The results of RAPD analysis revealed that a total of $87.88 \%$ polymorphism was found between the isolates, indicating molecular variability among the $X$. axonopodis pv. Punicae isolates. Information on the banding pattern for all the primers were used to determine genetic distance between the isolates and to construct a dendrogram by using unweighted pair group method (Nei's).

Based on the Nei's similarity coefficient a genetic similarity matrix was constructed to assess the genetic relatedness among the two isolates. The similarity coefficient value ranged from 0.20 to 0.88 across two isolates indicating high degree of genetic variation given in (Table 7). This ultimately means high range of genetic diversity among the isolates studied. The highest genetic similarity coefficient to an extent of 2.11 was recorded between Xap 4 and Xap5 isolates followed by 0.12 between Xap5 and Xap4 isolates. The dendrogram constructed by Nei's for RAPD analysis shows that isolates can be grouped into two major clusters viz. A and B (Fig.4) Cluster A containing single isolate Xap 4 (Nimgaon) and another cluster B distinct from cluster B containing single isolate Xap5 (Badnapur).
These results obtained in present study are in accordance with the reports of many earlier workers. Chakrabarty et al., (2005) standardized a protocol for extraction of genomic DNA from bacteria Xanthomonas axonopodis pv. malvacearum. Nunes et al., (2009) standardized a simple, quick and easy protocol for extraction of total DNA of the bacteria Xanthomonas axonopodis pv. phaseoli. William et al., (1990) showed that RAPD reaction mixtures can be created from several arbitrary nucleotide sequences, using short primers when amplified with the PCR. During annealing process, the primer sequences which are not directed to any known genetic locus, attached to the target DNA at random sites through a complementary sequence and permitted for initiation of polymerization. Giri et al., (2011) stated that bacterial blight caused by Xanthomonas axonopodis $p v$. punicaeis the devastating disease of pomegranate and the analysis of their RAPD profiles showed a high level of genetic variability among the strains of $X$. axonopodis pv. punicae. The cluster analysis based on similarity coefficients separated the sixteen strains into two major clusters. However, result reflected that the variation exhibited by the strains of $X$. axonopodis pv. punicaeis independent of their geographical location. Gadhe et al., (2016) studied the variability among the five isolates of Xanthomonas axonopodis pv. punicae by using 10 RAPD primers, out of which 07primers produces total 26 scorable bands with an average of 3.7 bands per primer. Out of 26 bands, 21 bands were found to be polymorphic and level of polymorphism was $80.76 \%$. The Jaccard's similarity coefficient showed that the isolate Loni (Code Xap I) was found to have higher value of similarity coefficient 0.88 with Astagaon (Code Xap II), whereas Talegaon (Code Xap III) was found to have lower value of similarity coefficient 0.20 with Rahuri (Code Xap V). 
On the basis of the present study, it could be concluded that the population of bacterial blight pathogen $X$. axonopodis $p v$. punicaein Jalna, Latur, Osmanabad and Beed district in Maharashtra are genetically heterogeneous and showed high level of genetic variability within a different geographical regions from RAPD profiles.

\section{References}

Anonymous, (2015). India Agristat revealing agriculture in India Statistical Information, www.indiastat.com.

Anonymous, (2016). India Agristat revealing agriculture in India Statistical Information, www.indiastat.com.

Chakrabarty, P. K., Sable, S., Monga, D. and Mayee, C. D. (2005). Polymerase chain reaction based detection of Xanthomoas axonopodispv. Malvacearum and cotton leaf curl virus. Indian J. Agric. Sci., 75: 524-527.

Chand, R. and Kishun, R. (1991). Studies of bacterial blight Xanthomonas campestris pv. punicae of pomegranate. Indian Phytopath.,44 (3):370-372.

Dhander, D. G., Nallathambi, P., Rawal, R. D. and Sawant, D. M. (2004). Bacterial leaf and fruit spot a new threat to Pomegranate orchards in Maharashtra state. A paper presented in: $26^{\text {th }}$ Ann. Conf. and Symp. ISMPP Goa University, Goa, India, pp: 39-40.

Gadhe, S. K., Antre, S. H., Ghorpade, B. B., Autade, R. H. and Mandlik, R. R. (2016). Studies on molecular variability among Xanthomonas axonopodis pv. punicae isolates collected from different locations. Int. J. Pure App. Biosci. 4 (3):160-166

Giri, M. S., Prasanthi, S. K., Kulkarni, S., Benagi, V. I., and Y. R. Hegde, (2011). Biochemical and molecular variability among Xanthomonas axonopodis $p v$. punicae strains, the pathogen of pomegranate bacterial blight. Indian
Phytopath.,64(1): 2-6.

Hingorani, M. K. and Mehta, P. P. (1952). Bacterial Leaf Spot of Pomegranate. Indian Phytopath. 5: 55-56.

Manjula, C. P. and Khan, A. N. A. (2003). Incidence of bacterial blight of Pomegranate (Punica granatum L.) in Karnata ka.Indian Phytopath. 56 (3): 341.

Mondal, K. K. and Sharma, J. (2009). Bacterial blight an emerging threat to pomegranate export of Indian Farming, 59: 22-23.

Muswad, Y. and Chavan, R. L. (2015).Molecular characterization of Xanthomonas axonopodis pv. punicae of pomegranate. Life Science Edge 2(2): 16-21.

Nunes, M. P., Mehta, A., Aguiar, P. H., Cia, E., Pizzinato, M. A., Chiavegato, E. J. and Mehta, Y. R. (2009). Analysis of genetic diversity among the isolates of Xanthomonas axonopdis pv. malvacearum of cotton. Summa phytopathology, 35(2): 105-109.

Petersen, Y., Mansvelt, E. L., Venter, E. and Langenhoven, W. E. (2010). Detection of Xanthomonas axonopodis pv. punicae causing bacterial blight on pomegranate in South Africa. J. of Austrian Pl. Path., 39: 544-546.

Vauterin, L., Hoste, B., Kesters, K. and Swing, J. (1995).Re classification of Xanthomonas. Int. J. Systemic Bacteriology, 45(2):472-489.

Wayde, J. E., Dange, A. S., Pagar, T. A., Sapkal, D. R. and Bansal, M. (2015). Assessment of the genetic diversity among oily spot (Xanthomonas axonopodis pv. punicae) pathogen of pomegranate by randomly amplified polymorphic DNA analysis. J. App. Nat. Sci. 7(2): 1s006-1011.

Williams, J. K. G., Kubelik, A. R., Livak, K. J., Rafalski, J. A. and Tyngey, S. V. (1990). DNA polymorphism amplified primers are useful as genetic markers. Uceic Acids Research, 18(22): 6531-6535.

\section{How to cite this article:}

Sahane, S.P., C. V. Ambadkar and Navgire K. D. 2017. Genetic Variability Amongst Xanthomonas axonopodis pv. punicae Studied by RAPD Banding Pattern Analysis. Int.J.Curr.Microbiol.App.Sci. 6(11): 1973-1982. doi: https://doi.org/10.20546/ijcmas.2017.611.234 